\title{
INVESTIGATION OF LOCAL SUCTION OPERATION IN THE DUST EMISSION ZONE
}

\author{
Shevchenko L.F., Ph.D., Associate Professor, \\ Bgedyx7@ ukr.net, ORCID: 0000-0003-3296-3007 \\ Odessa State Academy of Civil Engineering and Architecture \\ 4, Didrikhson str., Odessa, 65029, Ukraine
}

\begin{abstract}
The article discusses the theoretical foundations that are necessary when designing a local suction with the function of a dust collector for a powerful dust emission in aspiration dust collectors. The external forces that act on the ejection particles as they move in space are determined. A mathematical model of the operation of such a local suction is proposed using the example of a stone-cutting machine, where the absorption spectrum of the suction changes during the sawing of building stone, and the emission of sawing waste is a dusty mixture. The model is obtained by solving a system of nonlinear differential equations of particle motion in the field of air velocities of local suction and is implemented numerically. The absorption spectrum of local suction was obtained in relative units by approximating the velocity field found experimentally. The model takes into account the technological features of dust emission formation, its dispersed composition and the nature of the movement of dust particles when the absorption spectrum is constrained by the surfaces of the cut stone. As a result of studies of the process of local suction operation on the model, calculated dependencies are obtained that determine the relationship between the parameters of dust emission, the dimensions of the dust-receiving window, the effective suction rate in its cross section and the speed of transportation of dusty air through the pipeline. Based on the results of theoretical studies, a local suction design for a cutting tool of a stone-cutting machine has been developed, which, as field tests have shown, completely removes lumber waste from the working area and at the same time reduces the dust content of air in the driver's breathing zone to sanitary standards. The results obtained in this work can be a scientific justification for the engineering calculations of local suction of aspiration and dust cleaning plants in the construction industry.
\end{abstract}

Keywords: dust emission, local suction, suction spectrum, particle trajectory.

Introduction. Currently, in the factories of the construction industry, as well as in quarries and mines, sawing and processing of building stone are being carried out. In this process, the cutting tool of the machine emits about $40 \mathrm{~kg} / \mathrm{min}$ of waste products in the form of polydisperse dust. The operation scheme of the cutting tool is shown in Figure 1.

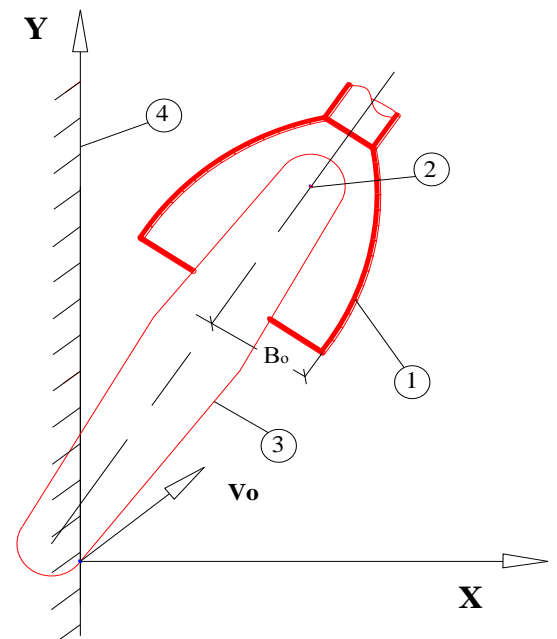

Fig. 1. The position of the cutting tool stone-cutting machine at the time of exit of the tool from the vertical saw cutting: 1 - dust shield; 2 - axis of rotation; 3 - cutting tool; 4 - stone working; $\mathrm{B}_{\mathrm{o}}$ - half the width of the dust collector; $\mathrm{V}_{\mathrm{o}}-$ is the initial input dust velocity vector

Depending on the type of technological operations, during the operation of the tool, both the initial input velocity and the particle trajectory in space are changing.

The dust shield of the stone-cutting machine extinguishes the kinetic energy of the discharge and partially protects the engineer from the ingress of large dust particles,

Bulletin of Odessa State Academy of Civil Engineering and Architecture, 2020, no. 79, page 152-158 
but at the same time the dust content of the workplace exceeds the value of sanitary standards by hundreds of times, and waste products of stone sawing should be removed manually.

Today, there are no effective engineering solutions to reduce air dust in this area of production, which not only reduces labor productivity, but also poses a direct threat to the health of workers.

Analysis of recent publications. There are publications [1-5], where the experience of designing and operating the local suction of aspiration devices is presented. However, such features as: building stone processing technology, high intensity and polydispersity of input dust, timevarying input dust path and the nature of the absorption spectrum of the local suction require a new approach to solving the problem of increasing its efficiency.

The aim of this work is the scientific justification in the design of the local suction of the aspiration device of stone-cutting machines. To achieve this goal, the following tasks were solved:

- a mathematical model of the trajectory of input dust in the working area of the engineer was developed;

- a model of the local suction absorption spectrum was constructed, which reflects a change in the air velocity vector at any point depending on the position of the cutting tool;

- the joint work of these two models was descried.

Materials and research methods. The article considers the operation of the local suction in the conditions of a variable absorption spectrum of a powerful input dust. To achieve this goal, mathematical methods are used to solve non-linear first-order differential equations, as well as approximation of the experimental field of air velocities in a local suction.

Research results. A mathematical model of the trajectory of the input dust is constructed under the following assumptions: all input dust particles do not interact with each other and do not rotate; the air flow that is ejected by the cutting chain from the cut of stone obeys the laws of an isothermal free stream. Taking into consideration the assumptions made, the dust particle is influenced by the aerodynamic drag force $\mathrm{W}$, the gravity $\mathrm{P}$ and the lateral force $\mathrm{P}$ caused by the airflow velocity gradient. The value of the aerodynamic drag force of a particle $\mathrm{W}$ can be determined from the expression:

$$
\mathrm{W}=\mathrm{C}_{\mathrm{o}} \cdot \mathrm{F} \cdot \pi \cdot \delta^{2} \cdot \rho \cdot(\mathrm{V}-\mathrm{U})^{2} / 8,
$$

where: $\mathrm{C}_{\mathrm{o}}$ - is the aerodynamic drag coefficient; $\mathrm{F}$ - dynamic shape coefficient; $\delta$ - is the diameter; $\rho$ - is the density of the particle material; $\mathrm{V}-$ is the flight speed of the dust particle; $\mathrm{U}-$ is the speed of the air stream that leaves from the saw cutting.

The value of gravity $\mathrm{P}$ can be determined from the expression:

$$
\mathrm{P}=\pi \cdot \delta^{3} \cdot \rho \cdot \mathrm{g} / 6
$$

where: $\mathrm{g}-$ is the acceleration of gravity.

The value of the lateral force acting on the dust particle, $\mathrm{P}$ is obtained from the expression:

$$
\mathrm{P}=\left(\pi \cdot \delta^{3} / 6\right) \cdot \rho \cdot \mathrm{V}_{\text {ot }} \cdot\left(\mathrm{dV}_{\text {ot. }} / \mathrm{dy}\right),
$$

where: $\mathrm{V}_{\mathrm{ot}}$ - is the relative velocity of the air flow on the horizontal coordinate of the center of the flow around it; $\mathrm{dV}_{\text {ot. } \mathrm{X}} / \mathrm{dy}$ - the first derivative of the projection of the relative velocity on the $\mathrm{X}$ axis to dy.

Based on the obtained expressions, a model of the movement of dust particles was constructed in the form of a system of nonlinear differential equations of the first order in projections on the coordinate axes $\mathrm{X}$ and $\mathrm{Y}$ :

$$
\left\{\begin{array}{l}
\mathrm{m} \cdot \mathrm{dV}_{\mathrm{x}} / \mathrm{dt}=-\mathrm{W}_{\mathrm{x}}+\left(\mathrm{V}_{\mathrm{y}} /\left|\mathrm{V}_{\mathrm{y}}\right|\right) \cdot \Pi_{\mathrm{x}} \\
\mathrm{m} \cdot \mathrm{dV}_{\mathrm{y}} / \mathrm{dt}=-\mathrm{W}_{\mathrm{y}}+\Pi_{\mathrm{y}}-\mathrm{P} \\
\mathrm{dx} / \mathrm{dt}=\mathrm{V}_{\mathrm{x}} \\
\mathrm{dy} / \mathrm{dt}=\mathrm{V}_{\mathrm{y}}
\end{array}\right.
$$


where: $\mathrm{m}$ - is the mass of speck dust; $\mathrm{V}_{\mathrm{x}}, \mathrm{V}_{\mathrm{y}}$ - are projections of the velocity vector on the coordinate axis.

The system of these equations was solved by the numerical Runge-Kutta method. The results of the solution for particles of various diameters are presented in graphical form in Figure 2.

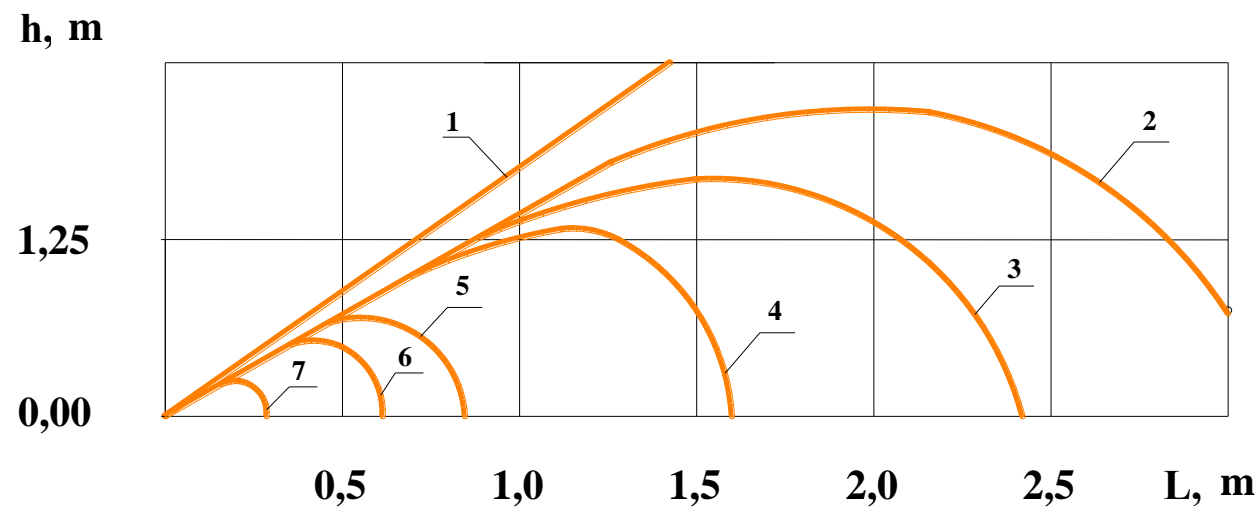

Fig. 2. Flight paths of particles of polydisperse input dust at a cutting tool speed of $\mathrm{V}_{\mathrm{o}}=12.1 \mathrm{~m} / \mathrm{s}$ and an initial air flow velocity $\mathrm{U}_{\mathrm{o}}=3 \mathrm{~m} / \mathrm{s}$ for particles with a diameter:

1 - 2500 тк; 2 - 1200 тк; 3 - 900 тк; 4 - 600 тк; 5 - 300 тк; 6 - 100 тк; 7 - 50 тк

As can be seen from the figure, the larger the dust particles, the greater the range of their input. Small particles, less than 50 microns, begin to fall out immediately near the cutting tool and then are partially carried out by air currents into the engineer's breathing zone. In addition, large particles in flight scatter into smaller ones, which create conditions for re-dusting the air. For the effective work of local suction its design must ensure full capture of dust emissions with particles from 2500 microns and below.

Due to the fact that the air velocity field in the local suction changes during operation, we have developed a model of the absorption spectrum that corresponds to stone processing technology. The model was built by minimizing deviations of lines of equal air velocities in the experimental field of a rectangular nozzle [6-7] and lines of equal velocities obtained in the form of displaced ellipses, the half-axes of which were considered as a function of relative speed in the equation:

$$
\left[\left(\mathrm{Y}_{1} / \mathrm{B}_{\mathrm{o}}\right)^{2}-\mathrm{C}_{1}\right] / \mathrm{B}_{1}^{2}+\left(\mathrm{X}_{1} / \mathrm{B}_{\mathrm{o}}\right)^{2} / \mathrm{A}_{1}^{2}=1 \text {, }
$$

where: $B_{0}$ - half of the wide side of the dust extraction window of the local suction; $A_{1}, B_{1}-$ the length of the semi axes of the ellipse; $\mathrm{C}_{1}$ - is the displacement of the axis of the ellipse; $\mathrm{X}_{1}, \mathrm{Y}_{1}-$ current coordinates of the velocity field.

The current value of the relative air velocity, in percent, $\mathrm{V}_{\text {в.1 }}$ was found by us from the solution of equation (5) and is presented in the form of an empirical dependence:

$$
\begin{aligned}
& \mathrm{V}_{\mathrm{B} .1}=5,208 /\left(\left|\left(\mathrm{B}_{1.1}+\sqrt{ }\left(\mathrm{B}_{1.1}^{2}+0,039 \cdot \mathrm{C}_{\mathrm{o} .1}\right)\right)\right|^{0,747}+0,052\right), \\
& \text { where: } \mathrm{B}_{1.1}=0,1\left(\mathrm{Y}_{1} / \mathrm{B}_{\mathrm{o}}\right)^{2}+0.095\left(\mathrm{X}_{1} / \mathrm{B}_{\mathrm{o}}\right)^{2}-0.079 ; \\
& \mathrm{C}_{\mathrm{o} .1}=0.81\left(\mathrm{Y}_{1} / \mathrm{B}_{\mathrm{o}}\right)^{2}+0.0025\left(\mathrm{X}_{1} / \mathrm{B}_{\mathrm{o}}\right)^{2}-0.002
\end{aligned}
$$

The direction of the velocity at any point of the absorption spectrum can be found by taking the derivative $d y / d x$ of expression 5 and equating it to $\operatorname{tg} \alpha_{0}$, where $\alpha_{0}-$ is the angle between the tangent to the line of equal potentials at the current point and the positive direction of the $\mathrm{x}_{1}$ axis. Then the angle between the velocity vector and the positive direction of the axis will be:

$$
\alpha_{1}=\pi / 2+\operatorname{arctg}\left|-\mathrm{B}_{1}^{2} \cdot\left(\mathrm{X}_{1} / \mathrm{B}_{\mathrm{o}}\right) /\left(\mathrm{A}_{1} \sqrt{ } \mathrm{B}_{1}^{2}-\left(\mathrm{B}_{1} \cdot \mathrm{X}_{1} / \mathrm{A}_{1} \cdot \mathrm{B}_{\mathrm{o}}\right)^{2}+\mathrm{C}_{1}\right)\right|,
$$


The obtained dependences (6-9), with an accuracy of 4\%, describe the main characteristics of the absorption spectrum of a freely located rectangular pipe, as shown in Fig. 3. Since dependences (6-9) are obtained in relative values, they are valid for any change rate in the exhaustion to the mouth of local suction. Due to the fact that during the local suction operation its absorption spectrum is distorted by the influence of the stone surface, we have elaborated the model of the absorption spectrum. This was done by superimposing the previously obtained model and its mirroring into each other.

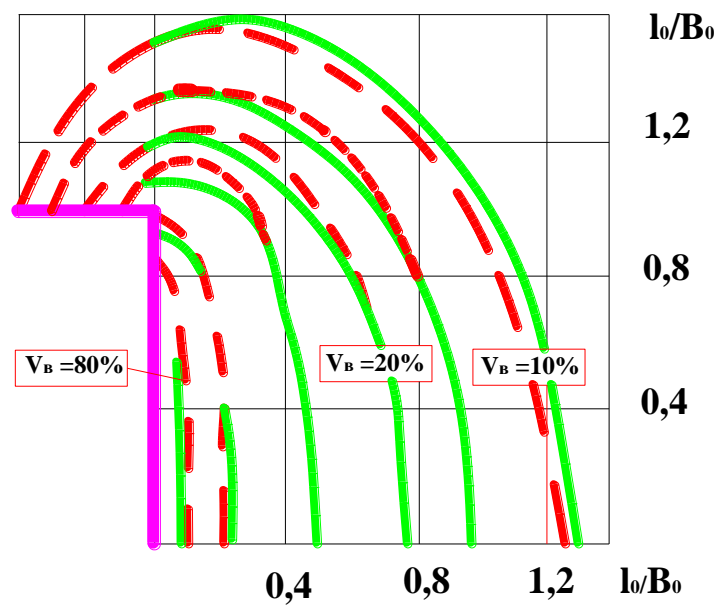

Fig. 3. The distribution of the relative rate of absorption of air in the spectrum of a rectangular pipe speed:

$1_{0} / B_{0}$ - relative coordinates of the point; $V_{\mathrm{B}}$ - relative suction rate at the design point; - experimental values; theoretical values

The joint solution of the input dust model and the absorption spectrum model of the local suction made it possible to obtain a model of the movement of the input dust particles in the area of the local suction of the aspiration device. The model was built by replacing in the formula (1) the value of the relative particle velocity ( $\mathrm{V}-\mathrm{U})$ by a value that takes into account the speed and direction of the air flow created by the local suction $\left(\mathrm{V}-\mathrm{U}-\mathrm{V}_{\text {в.1 }} \cdot \mathrm{V}_{\text {о.в }}\right) . \mathrm{V}_{\text {о.в }}$ - the specified initial air velocity in the cross section of the dust -receiving window of the suction. The solution of the system of equations (4), with the above changes, was carried out on a computer. The answers were repeated for various options for combining the dimensions of the dust-receiving window $\left(2 \mathrm{~A}_{\mathrm{o}} \times 2 \mathrm{~B}_{\mathrm{o}}\right)$ and the air velocity in its section $\mathrm{V}_{\text {о.в. }}$.

A graphic image of one of the calculation options is shown in Figure 4.

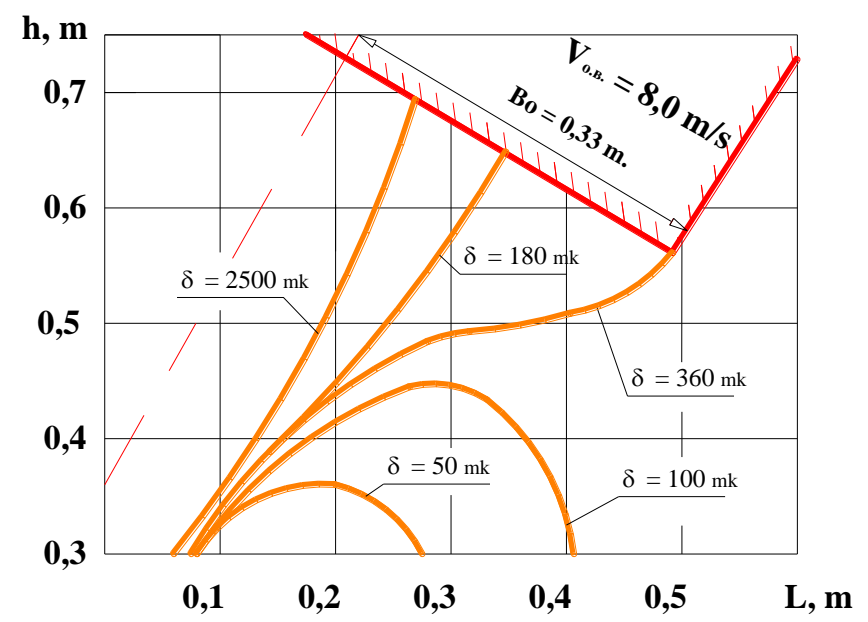

Fig. 4. Flight paths of dust particles in the local suction zone with dimensions of dust-receiving window $0.432 \times 0.660 \mathrm{~m}$ and $\mathrm{V}_{\text {о.в }}=8.0 \mathrm{~m} / \mathrm{s}$ :

$\mathrm{B}_{\mathrm{o}}-$ half the width of the dust box; $\delta$ - is the diameter of the dust particle 
As can be seen from the figure, particles with a factionalism of 2500 microns to 360 microns are completely ensnared by the local suction and particles less than 360 microns do not fall into the suction zone and are in the engineer's working area.

As the result of the analysis of more than seventy of such graphs for the full collecting of dust input, we have established the main characteristics of the local suction, which ensure its high efficiency. So, the dust-receiving window of the local suction should be the dimension of $0.2 \times 0.45$ meters; its perimeter is equipped with flexible cuffs with a depth of $l_{1}=0.1$ meters; suction speed on the axis of the dust -receiving window should be at least $6 \mathrm{~m} / \mathrm{s}$.

The flight paths of dust particles during such a local suction operation are shown in Figure 5.

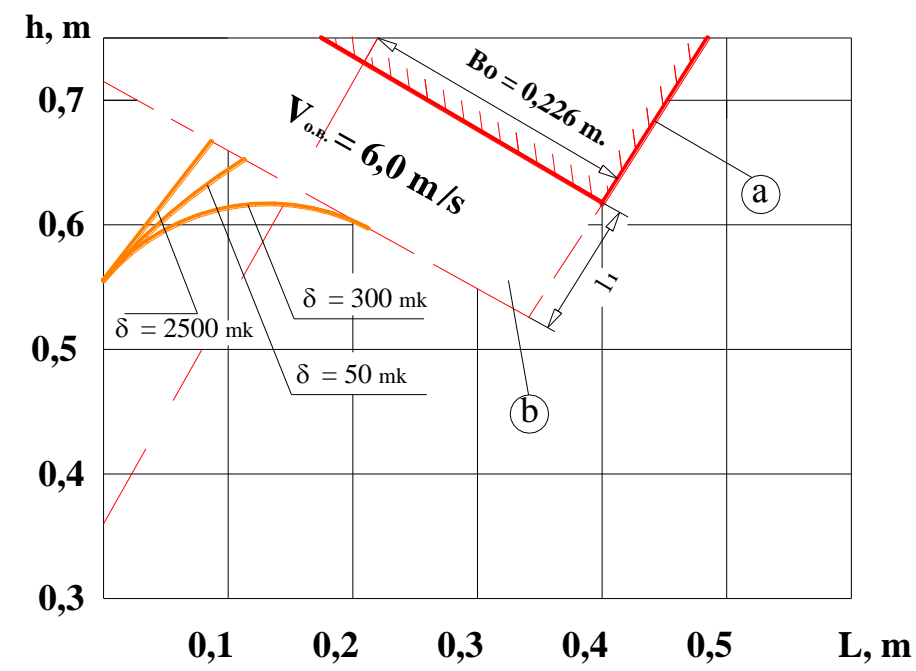

Fig. 5. Flight paths of input dust particles in the local suction area equipped with flexible frill: $a$ - local suction case; $b$ - flexible frill

A preproduction model of the local suction, manufactured according to the found characteristics, passed production tests, which confirmed its high efficiency in collecting of the entire input of dust. At the same time, the local suction developed by us allows to reduce the air dust content at workplaces of engineers to sanitary standards.

\section{Conclusions:}

1. The developed mathematical model of the flight of input dust particles in the local suction area takes into account the technological features of building stone processing and the change in the absorption spectrum of the local suction, which allows to analyze the process of waste removal during stone processing.

2. The obtained theoretical prerequisites for the justification of engineering calculations of the effective local suctions are confirmed by the production tests and can be recommended during their design.

3. The design of the local suction, designed taking into account the developed models, not only completely collects dust emission and mechanizes dust cleaning, but also reduces air dust in the workplaces.

\section{References}

[1] K.I. Logachev, "Modelirovanie vsasyvayushih fakelov mestnyh otsosov sistem aspiracii", dis. ... d-ra tekhn. nauk, spec. Teplosnabzhenie, ventilyaciya, kondicionirovanie vozduha, gazosnabzhenie i osveshenie, Voronezhskij gosudarstvennyj arhitekturno-stroitelnyj universitet, Belgorod, 2001.

[2] G.M. Pozin, "Mestnaya vytyazhnaya ventilyaciya - samyj effektivnyj sposob organizacii vozduhoobmena v pomeshenii", Zhurnal SOK, no. 10, pp. 17-19, 2006. 
[3] M.V. Teterev, "Sovershenstvovanie mestnyh otsosov sistem obespylivayushej ventilyacii pri proizvodstve silikatnogo kirpicha", avtoref. dis. na soiskanie nauch. stepeni kand. teh. nauk, spec. Teplosnabzhenie, ventilyaciya, kondicionirovanie vozduha, gazosnabzhenie i osveshenie, Volgograd. 2007.

[4] P.A. Kouzov, Osnovy analiza dispersnogo sostava promyshlennoj pyli i izmelchyonnyh materialov. Leningrad: Himiya, 1987.

[5] N.V. Polyakov, Chislenno-analiticheskie metody resheniya nelinejnyh kraevyh zadach. Dnepropetrovsk: DGU, 1991.

[6] A.G. Sotnikov, A.A. Borovickij, "Teoreticheski-eksperimentalnoe obosnovanie metoda optimizacii vozduhoobmenov $\mathrm{v}$ sistemah promyshlennoj ventilyacii", Inzhenernostroitelnyj zhurnal, no. 2. pp. 32-38, 2012.

[7] A.K. Logachev, Modeling of air and dust flows in the range of action of around suction funnel above an impel me able plane. Part1. A mathematical model and algoritm for its computer impel mentation. Refractories and Industrial Ceramic, no. 6, pp. 679-683, 2016.

\title{
ДОСЛІДЖЕННЯ РОБОТИ МІСЦЕВОГО ВІДСМОКТУВАЧА В ЗОНІ ПИЛОВОГО ВИКИДУ
}

\author{
Шевченко Л.Ф., к.т.н., доцент, \\ Bgedyx7@ukr.net, ORCID: 0000-0003-3296-3007 \\ Одеська державна академія будівництва та архітектури \\ вул. Дідріхсона, 4, м. Одеса, 65029, Україна
}

Анотація. У статті розглянуто теоретичні основи, які необхідні при конструюванні місцевого відсмоктування з функцією пилоприймача потужного викиду пилу в аспіраційних пилозбиральних установках. Визначено зовнішні сили, які діють на частинки викиду при їх русі в просторі. Запропоновано математичну модель роботи такого місцевого відсмоктування на прикладі каменерізної машини, де спектр всмоктування відсмоктування змінюється в ході розпилювання будівельного каменю, а викид відходів розпилювання являє собою пилоповітряну суміш. Модель отримана шляхом розв'язання системи нелінійних диференціальних рівнянь руху частинок у полі швидкостей повітря місцевого відсмоктування і реалізована чисельним методом. Спектр всмоктування місцевого відсмоктування отриманий у відносних одиницях шляхом апроксимації поля швидкостей знайденого експериментальним шляхом. У моделі враховані технологічні особливості утворення пилового викиду, його дисперсний склад i характер руху частинок пилу при стисненні спектра всмоктування поверхнями випилюється каменю. В результаті досліджень процесу роботи місцевого відсмоктування на моделі, отримані розрахункові залежності, які визначають зв'язок між параметрами пилового викиду, розмірами пилоприймального вікна, ефективною швидкістю всмоктування в його перетині і швидкістю транспортування пилоповітряного середовища по трубопроводу. На основі результатів теоретичних досліджень розроблена конструкція місцевого відсмоктування до ріжучого інструменту каменерізної машини, яка, як показали натурні випробування, повністю видаляє відходи пиломатеріалу з робочої зони і при цьому знижує запиленість повітря в зоні дихання машиніста до санітарних норм. Результати, отримані в роботі, можуть бути науковим обгрунтуванням при інженерних розрахунках місцевих відсмоктувачів аспіраційних і пилозбиральних установок в будівельній індустрії.

Ключові слова: пиловий викид, місцевий відсмоктувач, спектр усмоктування, траєкторія руху часток. 


\title{
ИССЛЕДОВАНИЕ РАБОТЫ МЕСТНОГО ОТСОСА В ЗОНЕ ПЫЛЕВОГО ВЫБРОСА
}

\author{
Шевченко Л.Ф., к.т.н., доцент, \\ Bgedyx7@ukr.net, ORCID: 0000-0003-3296-3007 \\ Одесская государственная академия строительства и архитектуры \\ ул. Дидрихсона, 4, г. Одесса, 65029, Украина
}

\begin{abstract}
Аннотация. В статье рассмотрены теоретические основы, которые необходимы при конструировании местного отсоса с функцией пылеприёмника мощного выброса пыли в аспирационных пылеуборочных установках. Определены внешние силы, которые действуют на частицы выброса при их движении в пространстве. Предложена математическая модель работы местного отсоса на примере камнерезной машины, где спектр всасывания отсоса меняется в ходе распиловки строительного камня, а выброс отходов распиловки представляет собой пылевоздушную смесь. Модель получена путём решения системы нелинейных дифференциальных уравнений движения частиц в поле скоростей воздуха местного отсоса и реализована численным методом. Спектр всасывания местного отсоса получен в относительных единицах путём аппроксимации поля скоростей найденного экспериментальным путём. В модели учтены технологические особенности образования пылевого выброса, его дисперсный состав и характер движения частиц пыли при стеснении спектра всасывания поверхностями выпиливаемого камня. В результате исследований процесса работы местного отсоса на модели, получены расчётные зависимости, которые определяют связь между параметрами пылевого выброса, размерами пылеприёмного окна, эффективной скоростью всасывания в его сечении и скоростью транспортировки пылевоздушной среды по трубопроводу. На основе результатов теоретических исследований разработана конструкция местного отсос к режущему инструменту камнерезной машины, которая, как показали натурные испытания, полностью удаляет отходы пиломатериала из рабочей зоны и при этом снижает запылённость воздуха в зоне дыхания машиниста до санитарных норм. Результаты, полученные в работе, могут представлять собой научное обоснованием при инженерных расчётах местных отсосов аспирационных и пылеуборочных установок в строительной индустрии.

Ключевые слова: пылевой выброс, местный отсос, спектр всасывания, траектория движения частиц.
\end{abstract}

Стаття надійшла до редакції 10.03.2020 